\title{
FOOD LABELING AND GOOD MANUFACTURING PRACTICES TRAINING FOR REGION IV-BANTEN "LEMBAGA BARISAN MUDA WIRAUSAHA INDONESIA” CULINARY ENTREPRENEURS
}

\author{
Intan Nurul AZNI ${ }^{1 *}$, Rahmawati RAHMAWATI ${ }^{2}$, Muhammad Fajri ROMADHAN ${ }^{3}$, Yandi ANDIYANA ${ }^{4}$ \\ Sahid University, Jakarta \\ *intannurulazni@gmail.com
}

\begin{abstract}
The partner in this activity were the Culinary Entrepreneurs of the Region IV-Banten "Lembaga Barisan Muda Wirausaha Indonesia". Most of the total members of the Region IV-Banten "Lembaga Barisan Muda Wirausaha Indonesia" are engaged in the culinary industry. However, only a small number already have food registration certificate from local health department and National Food and Drug Agency (BPOM). One of the requirements for applying for food registration certificate is to obtain a Food Safety Counseling certification of Good Manufacturing Practice (GMP). The solution offered in this activity is to provide offline and online training through Zoom meetings media regarding the food labeling and Good Manufacturing Practices (GMPs) training so our partner can apply food registration certificate easily. Due to the pandemic conditions, the proposing team carried out activities offline and online. Offline activities are carried out by adhering to health protocols. The methods used in this activity were socialization of food registration certification regulations to the partners, and training on labeling of processed food products, training on good manufacturing practices (GMPs), and evaluation of the training provided. The socialization activity was carried out on Saturday, February 27, 2021 at the Ar Rahman Training Center BSDSouth Tangerang. The results of the evaluation showed that the training participants increased their knowledge about food labeling and GMP by $88 \%$.
\end{abstract}

Keywords: Food Label, Food Registration Certificate, GMPs, Training

\section{BACKGROUND}

Lembaga Barisan Muda Wirausaha Indonesia (LBMWI) is an organization consisting of young entrepreneurs in Indonesia. LBMWI consists of 4 regions, namely regional 1, II, III, and IV. Our partner in this community service activity was Region IV-Banten "Lembaga Barisan Muda Wirausaha Indonesia".

Some of the members of regional LBMWI IVBanten are engaged in the culinary industry. However, currently only a small number of the members that had food registration certification from local health department and National Food and Drug Agency (BPOM). According to the Regulation of the Head of the National Food and Drug Agency no. 12 of 2016, one of the requirements for food registration certification is fulfill the examination of the good manufacturing practices (GMPs) and fulfill the good distribution practice of processed foods (BPOM, 2016). Nevertheles, the food registration certification cannot be obtained easily. It takes quite a long time, quite high cost, and a lot of requirements.

Foodborne diseases are a public health problem that is still happening today (Cusato, 2014). Each year, unsafe food causes 600 million cases of foodborne diseases and 420000 deaths worldwide. Foodborne diseases are preventable. To build strong and resilient national food safety systems and provide consumers to make safe food choices, WHO has a critical role in taking global leadership in investment and coordinated action across multiple sectors (WHO, 2021). Foodborne diseases can be minimized by practicing GMPs. GMPs also has a role as the first step in the development of the hazard analysis and critical control point (HACCP) system in food industries. The implementation of GMPs requires investments to improve the hygienic design of equipment and facilities, maintenance and sanitation practices, control of operations, personal hygiene, transportation, and training in order to ensure the fabrication of safe foods (Cusato, 2014).

The role of labels on food products is very important. The proper and correct labels make it easier for consumers to choose food products. Labeling of food products can be used as the main source of information about packaged food. The labeling aspect also can be an effective tool for quality control and food safety (Septian, 2014).

One of the scope of activities of LBMWI is coaching in the education, training, and mentoring of small and medium enterprises (SMEs), therefore a collaboration is held between the community service team from Sahid University Jakarta with Region IV-Banten "Lembaga Barisan Muda Wirausaha Indonesia" in the form of training on Labeling and Processed Food Production Methods Good (CPPOB) for partners so it is hoped that the partners will find it easier to get food registration certificate

\section{METHOD}

Based on the problems faced by Culinary Entrepreneurs of the Region IV-Banten "Lembaga Barisan Muda Wirausaha Indonesia", the solutions offered is using the following methods:

1. Socialization of food registration certification regulations to the partners

2. Training on labeling of processed food products

3. Training on good manufacturing practice (GMP)

4. Evaluation

Due to the pandemic conditions, the proposing team carried out activities offline and online. Offline activities are carried out by adhering to health protocols. 


\section{RESULTS AND DISCUSSION}

The series of community service activities for Culinary Entrepreneurs of the Region IV-Banten "Lembaga Barisan Muda Wirausaha Indonesia" were carried out simultaneously on Saturday, February 27, 2021 at the Ar Rahman Training Center BSD-South Tangerang. Due to the COVID-19 pandemic, the activities consist of offline and online through Zoom Meeting media (Figure 1 dan 2).

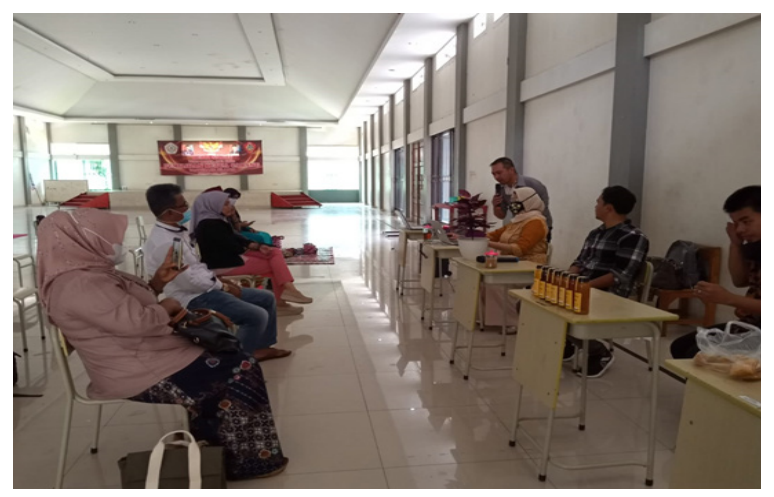

Figure 1. Offline community service activities

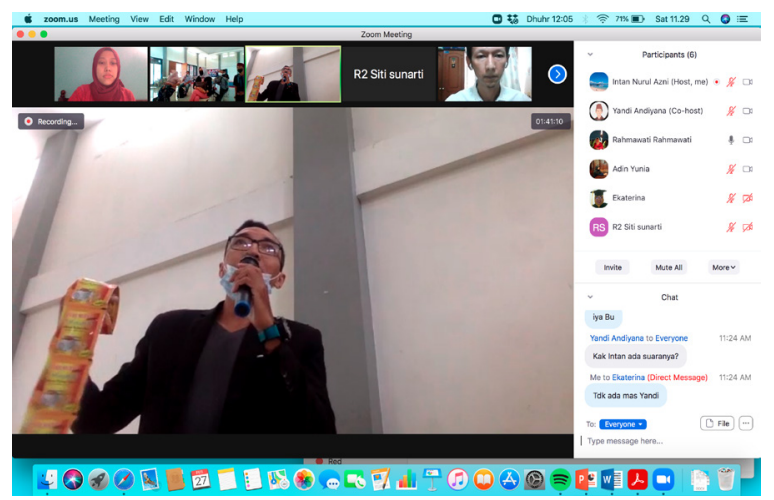

Figure 2. Online community service activities through Zoom Meeting media

The series of Community Service activities for our partners Partners IV-Banten include:

A. Socialization of food registration certification regulations

The socialization of food registration certification regulations from local health department and National Food and Drug Agency (BPOM) was carried out on Saturday, February 27, 2021 at the Ar Rahman Training Center BSD-South Tangerang. In addition to being carried out offline, this socialization activity is also carried out online through the media zoom meeting. This is due to the pandemic conditions, so the proposing team arranges activities to be carried out offline and online. Offline activities are carried out by adhering to health protocols.

The socialization of food registration certification regulations need to be carried out because food distribution permits cannot be obtained easily and take a long time, high costs, and quite a lot of requirements. So the partners need to be provided with sufficient knowledge regarding this matter. The socialization activity for the food registration certification regulations can be seen in Figure 3.

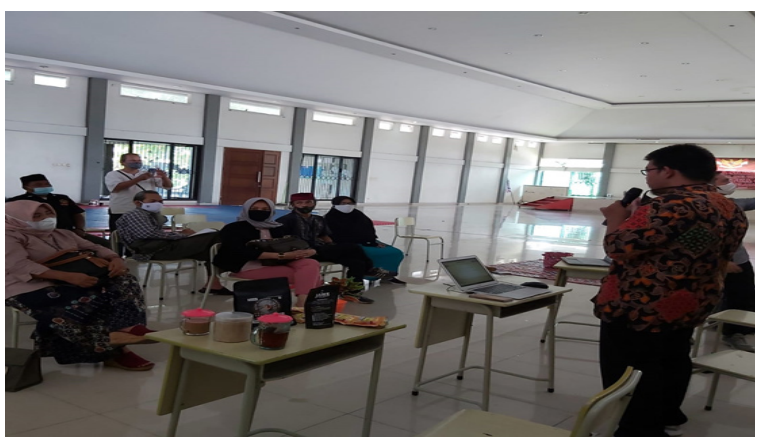

Figure 3. Socialization of food registration certification regulations

B. Training on labeling of processed food products

The socialization of regulations and training for processed food product labeling aims to make partners aware of the correct label requirements for food products in accordance with the Regulation of the National Food and Drug Agency (BPOM) No 31 of 2018 concerning Processed Food Labels. This activity is carried out offline. The Socialization of Regulations and Training on Labeling Processed Food Products can be seen in Figures 4 and 5.

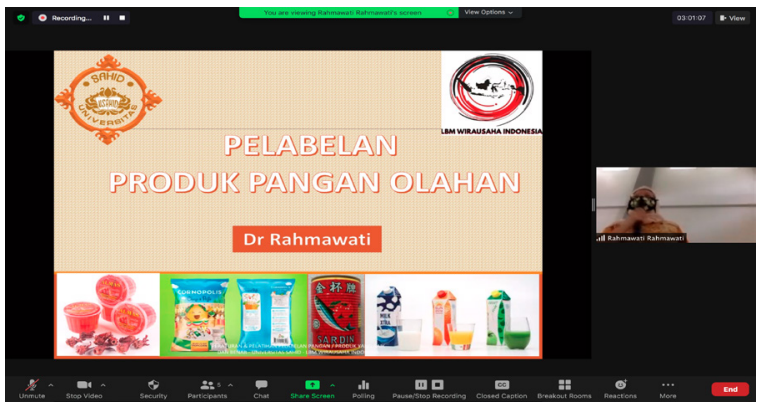

Figure 4. Training on labeling of processed food products (online)

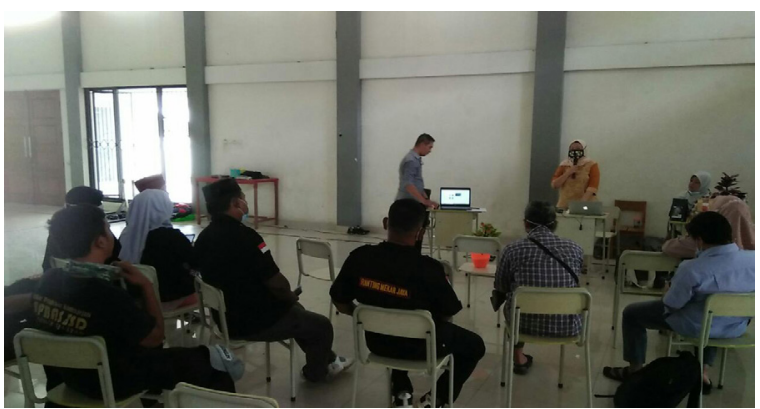

Figure 5. Training on labeling of processed food products (offline)

C. Training on good manufacturing practice (GMP)

Training on good manufacturing practice (GMP) aims to enable partners to produce quality processed food, suitable for consumption, and safe for health. The material presented refers to the Regulation of the Minister of Industry of the Republic of Indonesia No.75/ M-IND/PER/7/2010 concerning Guidelines for Good Manufacturing Practices for small and medium enterprises (SMEs) and the National Food and Drug Agency (BPOM) No.HK.03.1 23.04.12.2206 of 2012 concerning good manufacturing practices for home industries. The GMP training activities can be seen in Figure 6 . 


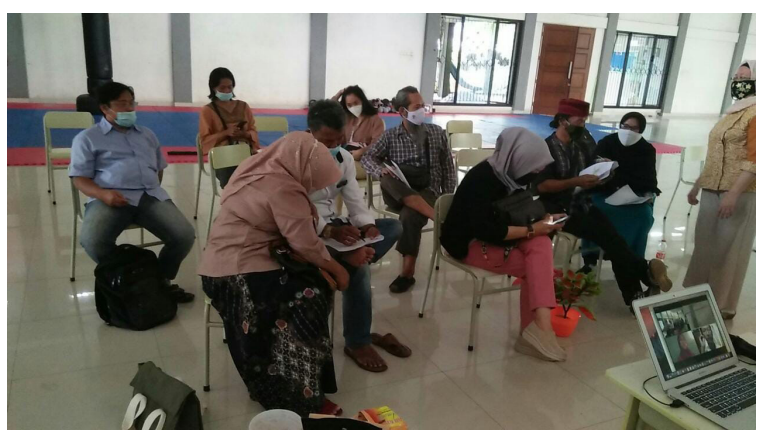

Figure 6. Training on good manufacturing practice (GMP)

D. Evaluation

To find out that there is an increase in partner knowledge regarding the training, we gave pre and post tests to the partners. There are 10 questions related to the training material with the same questions for the pre and post tests. Based on the results of the assessment, $88 \%$ of the trainees got the higher scores on the post-test than on the pre-test. The pre and post tests were only given to participants who attend offline training. The evaluation activities for the training provided can be seen in Figure 7.

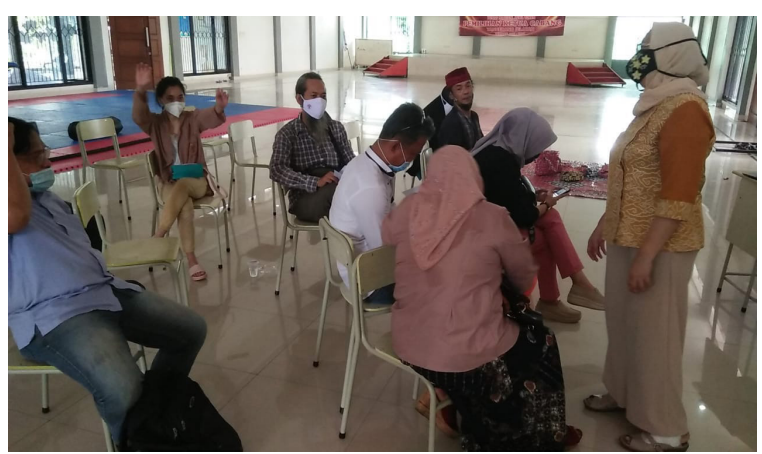

Figure 7. The evaluation

\section{CONCLUSION}

Community service activities of food labeling and Good Manufacturing Practice (GMP) training for the Region IV-Lembaga Barisan Muda Wirausaha Indonesia was conducted on Saturday 27 February 2021 at the Ar Rahman Training Center BSD-South Tangerang. This activity consists of offline and online through the zoom meeting media. These activities include socialization of food registration certification regulations to the partners, and training on labeling of processed food products, training on good manufacturing practice (GMP), and evaluation of the training provided. The results of the evaluation showed that the training participants increased their knowledge about food labeling and GMP by $88 \%$.

\section{ACKNOWLEDGMENT}

This Community Service activity was fully funded by Batch IX Community Service Grant of Sahid University Jakarta No. 29.05/USJ-11/H.54/2020 on March 6, 2020.

\section{REFERENCES}

Badan Pengawas Obat dan Makanan. (2016). Peraturan Kepala Badan Pengawas Obat dan Makanan RI no 12 Tahun 2016: Pendaftaran Pangan Olahan [Internet]. BPOM RI. [cited 5 Februari 2020]. Available: https://www.ukmindonesia.id/upload/ attachment/doc/doc_Perka_BPOM_12_2016_ Pendaftaran_Pangan_Olahan.pdf

Cusato, S., Gameiro, A. H., Sant'Ana, A. S., Corassin, C. H., Cruz, A. G., \& De Oliveira, C. A. F. (2014). Assessing the costs involved in the implementation of GMP and HACCP in a small dairy factory. Quality Assurance and Safety of Crops \& Foods, Vol 6(2), 135-139.

Septian, J., \& Rahayu, W. P. (2014). Pengetahuan pelabelan produsen industri rumah tangga pangan di kota Bogor. Jurnal Mutu Pangan: Indonesian Journal of Food Quality, Vol 1(2), 145-150.

World Health Oragnization. 2021. Estimating the burden of foodborne diseases [Internet]. WHO. [cited July 29 2021]. Available: https:/www.who.int/activities/ estimating-the-burden-of-foodborne-diseases 